\title{
Erratum to: DNA damage in the presence of chemical genotoxic agents induce acetylation of H3K56 and H4K16 but not H3K9 in mammalian cells
}

\author{
Rahul Kumar Vempati • Devyani Haldar
}

Published online: 21 June 2011

(C) Springer Science+Business Media B.V. 2011

\section{Erratum to: Mol Biol Rep}

DOI 10.1007/s11033-011-0739-9

The senior author Devyani Haldar of this study was inadvertently omitted. The correct corresponding author and affiliation details are given here.
The on-line paper should be cited as: Vempati RK \& Haldar D. DNA damage in the presence of chemical genotoxic agents induce acetylation of H3K56 and H4K16 but not H3K9 in mammalian cells. Mol Biol Rep 2011 May 15.

This work was supported by a grant from Institute of Life Sciences to D. Haldar.

The online version of the original article can be found under doi: 10.1007/s11033-011-0739-9.

R. K. Vempati · D. Haldar $(\bowtie)$

Department of Biology, Institute of Life Sciences, University of Hyderabad Campus, Gachibowli, Hyderabad 500046, India e-mail: devyanih@ilsresearch.org 